\title{
On the connotation and essential features of Chinese teaching service type university
}

\author{
Yo Zhao Weiping \\ (Higher Education Research Center, Nanyang Institute of Technology, Henan, 473004, \\ china) \\ Weipingzhao@163.com
}

\begin{abstract}
Teaching service type university is One new classification-based universities. Set off from China's actual conditions, Bring forward the concept of the teaching serves type university is to break the teaching universities' Development allocation, to provide new development direction of the New-built local universities.
\end{abstract}

Keywords: Teaching serves type university; Social service function Connotation; Essential features

The gradually complicated development of the present age society brings a lot of social problem, such as the steadily downhill of the Ethics morality, which requires universities to carry out social service right away, not only the technical transfer, and not to the College of science and engineering, all kinds of the universities have the opportunities to play more active effect. From the angle of the universities function to Carry out the classification of universities is not to the Carry out classification explanation on university , but to carries out the reform way of higher education. Bring forward the" teaching serves type university" concept is to break the teaching universities' Development allocation, and to provides new development direction of the Newbuilt local universities. Because it is from the China's actual conditions to form the Classification concept, so it is the Chi- nese characteristics' teaching serves type university

\section{Social service classification system is the innovation of the Carnegie foundation 2010}

Tradition's Carnegie foundation system is the second Treating Making use of the country 's and Other organization data to analyze the American universities, but the data do not include some important scientific research and the served contract data of universities. In 2010, Carnegie Foundation developed a new Index system-using Social service classification to reflect these important activities .Social service classification is a selectivity classifies, and it volunteered universities to choose participation Liberty. It relates to magnanimous thrown into, and it requires the Universities who participates to indicate that the social service is the university's clear and important mission, to Provide participating the data in action and the flexible concrete example, which included two types: the course participated in and make prolongation partnership. ${ }^{1}$ The responsible person Alexander-McCormick of Carnegie foundation says that the appearing of Carnegie Social service classification system is a exciting movement, which define and make rubbings from the classification system of the universities again, and having affirmed social service Importance in higher education further. The chairman of 
Carnegie foundation LeeS - Shulman also says that University today requires to discover the renewal and much better way to get in touch with and to service the society, and also needs to Readjust themselves' service society to a certain preferential higher location and the universities participating in foundation selectivity classification system has provided some very good examples, which have reported the fine buddy relation between them and the community. The appearing of Selectivity classification system is not only Sharpening the further works of the communicate and the cooperation to the university ,but also beneficial to guiding universities to carry out social service. We can foresee that many more universities will participate the Selectivity classification system, and that the social service selectivity classification system will also improve and to further perfects become in a few years.

\section{The international development of the service type university}

Abroad' s research about the service type university increases by gradually, and the university pattern of it is gradually limpid. Know and study the abroad Service type university's Connotation and development pattern can help us to learn the Idea of the Service type university enthusiastically.

\subsection{The Connotation of the Service type university}

The Service type university was put forward in the 1980s. In the 1980s, the west Economy was decaying, and the higher education of USA and Europe are at a stands till after greatly development. With the government's enlarging throwing to higher education, the beneficial result of Higher education funds and the Value and society adaptability provided service by higher education organization and so on, which have caught the public broad attention and have questioned. The public thinks that some research universities supported by large amount of fund, which don't make necessary directing service progress on the society economy environment and they isolates self from society need, is not worth holding out. Another, some public points out that although the different branch of the universities who learns enthusiastically to provide some service ,but for its badly Organization, the simultaneous service is also short of pertinence. (2)

Such is compelling the universities to adapt to the economy and society status changing unceasingly. Those , who do not have attraction to students and cannot get the funds of the government and enterprise, is able to be confronted with final breakdown. Under such background, from Study type university, Service university motion " is in the ascendant, and also a new service type university also begins to appear. The professor of Educate research centre and the compare with international department of Norway Oslo university Aruide brought forward the "service type university" concept. $\mathrm{He}$ points out the "service" significance depends on "propagation, application and upkeep take knowledge as basis, to own the applicability technology of certain customer, no matter where the customers are" ${ }^{\text {, } 3}$.The most important characteristic of the "serving type university" lies in "the market-oriented, to produce the competitive product within marketplace knowledge". Its funds earn source also needs to come to by the relevant service to knowledge-base economy, the exists also need to look at its buying request concluded by the government or enterprise, being able to satisfy the parents and the students who buys teaching and study service, think highly of the universities competition in the marketplace mainly. 
Judging from the development of USA service type university, the service type university divides into making profit's also nonprofit. Some studying type university is forced to carry out concentrating reformation and to appropriate to gives its studying and teaching to the public who needs. Some new-built higher education organization, like the company, provides the public different knowledge need looking. USA scholar Wilhelm Pass summarizing out its principal character, having compared the tradition research type university with late-model "service type university", He thinks that "the service type" learns the application concentrating on emphasizing "occupation" and knowledge application, majority teaching among them gives first place to shortterm course mainly, and carries out teaching outside campus. It's development tending to market-oriented, using the contract form to satisfy the customers. In a word, Establishing the occupation academy, interposing the short-term course, the BA queen degree and adapting to the customers personnel training, employing many part-time employee, contract at the same time, carrying out external service, serving a plan and signing a treaty to afford. Establishing the service contract is the essential features of the "service type universities". At the same time, the managing pattern of the "service type university", which also exceeding the tradition frame higher education as attention university runs efficiency and assets added value role mainly.

The university president plays as attention university runs efficiency and assets added value role mainly. The universities research is rational only when being thought that just during the period of the satisfied prompt request and technology need. Its valuation depends on its ability of the graduate enters the labor market.

\subsection{The development pattern the ser- vice type universities}

The service type universities appears in the 1990s and then develop quickly. From its development history, there are about four types: Academic service university, Service university, Enterprise university and Company university. The voice of Criticizing to Service university shuts out largely. The Enterprise university and Company university is also the Academic organization and the Bureau.

People questions its academic organization qualification, one company who is driven by profit learns enthusiastically, providing is the "education" or only the working and the training qualification? Does its profit whether or not to contradict with society benefit mutually? How to preserve and own the fundamental values of the universities? Is big academic freedom able to be in a higher education organization lining survival to satisfy economy need but gaining financial support mainly by providing services? Which service type higher education organization is able to keep the fundamental value and characteristic, such as the intelligence completeness, the characterized probes into, to own the right idea of studying and understanding? criticizes nature? How the university of company that profit-push maximizes to balance avaricious capital instinct and preserves its owns certain learning horizontal?

But, beyond all doubt, service type university expands in USA uninterrupted growth. In 1991 only having one making profit serves type university was listed company, but in 1999, such an education company has arrived 70 .

Some observers think that the higher education estate having boundless development tendency. At the same time, Some of nonprofit university are also starting their making profit enterprise, such as continuous educational college of New York、 figure medium company in 
Columbia University's etc. gradually, The difference of the universities making profit and the nonprofit universities, are getting diminish and mix up ${ }^{(4)}$. That academic service university and criticizes nature service university is that tradition universities that faces the change to serving type university, Deweier Tejie does his utmost to praise highly criticizing the service type university pattern. He taken Norway Oslo as case, has explained that service type university is able to blend with the academic tradition value and what be involved in external activity successfully.

\section{The connotation of the service type teaching university}

As for broad wide angle, university all has service. From as soon as beginning, university are giving service to country and personal, to the modern society, university beginning to be one part of enterprise, and beginning to give service to the enterprise and the economy. Judging from the development of the USA service type university, various type universities are becoming service type universities.

On one hand this change depending on knowledge and economical relation, another lies in the university's established logical reaction accord with the blaming and the accepts to difficult position.

At present, lot of university initiative adjustment to carry out social service, formulating a policy to promote the alliance with the government and industrial enterprise enthusiastically, hopes that higher education can adapt to the needs of occupation knowledge-base economy times changes unceasingly, and makes it's "service" rise.

Fleetness development China requires great majority society organization permanency change. Enterprise has already experienced the process of reorganizing and reconstructing, govern- ment organization has also been facing the serving type government change, the various public utilities unit, serving organization and so on are also in ceaseless change. In the new era, facing the challenge and opportunity brought forward by the world, major China universities also make great efforts to serve the era, and to make uninterrupted growth for the purpose of much better being.

Though the universities have made great effort of servicing the society, there are also no ultimate transform on the aspect of the mission and the characterize changes to the common universities. Major universities are in passive answering in the field of social service. New-built local universities should ask the development targets for sustainable development, function and mission again. The new-built local universities leader need to ask himself that "whom we are serve for ?" and "How does have the ability to serve much better with us?" We must have the long-term strategy to answer the challenge and seize the development opportunity. Society requires universities to satisfy society's various need and also to keep the tradition of the universities to train talented person, to develop knowledge and to transform the culture, If the universities are not able to satisfy society's need, the new organization comes to undertake these responsibility, such as the university of company, enterprise university etc surely.

Universities needs sustainable development and also need to serve the sustainable development society, to meet the service society need and to keep the teaching and scientific research level, and also to cultivate the professional personnel fitting with the needs of the society, and to care for student's all-round development. The train of target and mission is an altitude relevance, isolated one aspect job will carry out the universities mission and target, so the universities' Social ser- 
vice function connotation rises thereby from simple direct service to opening up an all-direction exhibition service.

We survey by the fact of the newbuilt universities development reality and learn the concept to the future, so we bring forward the service type university concept. The "teaching service type university " is that: adjusted to the knowledge-base economy social development course, to face the popular higher education and a fierce marketplace environment, to take the talented person to serve the local economic and social development, to train application, to be united a plan, to integrate teaching, to study the flexible public service, and to be on the road of "Study product grinds integration". And to build the interactive fine relation with the place, and at last to build a late-model university who are different in tradition university, interacts with the place equally in the field of educating, teaching, study of science, and social service etc.

\section{The essential features of the Teach- ing service type university}

\subsection{The purpose is to serve the local economic and social development serves}

The purpose core of teaching service type university is that "It must make contribution to the local economic development." Accordingly to this purpose, the school all need to serve for development of this locality, from special field interposing, teaching thought and method, educational system and degree to the graduate, which all need to comply with local present and long-term development. The local need is that the finality standard to decide the course and degree demands. It is no doubt that the purpose of the science study is to serve the community economic growth.

Melting the service society's thought with a school guiding thought, make the school to bear the integration of the economy and educating science and technology, not only being able to satisfy society demand of talented person, also being able to make universities to have a continue developing.

\subsection{All-direction service social system}

The service type university ought to be different to the tradition universities in the field of teaching concept, teaching method, study content, research method, social service range, teaching pattern and teaching innovation etc.

4.2.1 Change concept, unite plan teaching, study and make public service flexible

This service strategy demands more highly to university, requires that university takes society as centre, is not to use school as centre to considers teaching, studying and service. As fact, it requires that the service type university to adopt one kind of the total strategy plan to take participate in the local economy and social development. Teaching, studying and public service, the three aspect should come to think entirety but not to take the three big function simplification as an unique service function, and not to emphasize service to abandon the teaching.

4.2.2 According to the need of local economy, the society requires and the developing trend to adjust the discipline and special field

In the building special field, paying great attention to the strategy of new industry and society economy development need, optimizing the division of disciplines, cultivating the characteristic field, to form the special community service field, to strengthen the science and study teaching service and to improve the economical ability of local economic growth need.

4.2.3 To reform course offered, carry out service studying

For improving the ability of university service society, some of the universities 
integrate the course with the community and enterprise to carry out a service activity through the continuous extracurricular service learns, service in course learns, all together service learns for one time merely to restructure the university, the scholar, the student and the community's resource, and to train the student's technical ability and to deep the students' service spirit and to strengthen the wish that the student serves to the society, enterprises, and the community.

4.2.4 To build up a clear and definite mission, market-oriented, have the transparency commercial project decisionmaking system.

To build the market mechanism universities service pattern of giving first place to the compensable project and contract service, to change the current situation at present that teacher chooses research problem liberty, with society services range (urgent development need of future) as the core, to certain the characteristic studying and teaching priority, and to gather the strength studying. As this, on one hand we can plan to build-up the research result, on another we can raise funds for school.

4.2.5 To reinforce the road with industry and commerce enterprise and to take the rode of "the integration of product study and research"

Changing the way of running schools that oneself closes, to take the rode of "the integration of product study and research ".To make university not only be the organization of producing knowledge's, but also the knowledge industry's establishing person and operator, to changes scientific research result into knowledge product and to create out economic value directly.

4.2.6Carrying out richer various directness social service to satisfy local community need, and becoming local society's leading factor.

\subsection{The creation of the inner social service operating and the manage- ment mechanism}

Tradition organization of the university applies to play mainly the teaching function, so the university ought to break to some extent in this respect. Changing from the teaching type to the teaching service, related not only the idea of running a school, but also need to fit the basic structure change, keeping elasticity of the inner structure, can separation or unity the function, flexible application freely, and to build the self-development higheffect science restraint mechanism. Include a competitive and incentive mechanism, machine-made throwing into, innovative mechanism, as well as decision-making mechanism, control mechanism, supervision and control mechanism. Inside of universities building special conscientious service organization carry out social service and put into effect concretely. We should formulate a policy actively to boost university and the government forming the alliance working together with industrial enterprise in research project and make university becomes the service type university.

\subsection{The mirror of the Interactive Uni- versity}

The teaching service type university should be geared to the needs of place, acquaintance place, research place, service place, studying the place and to molten to enter place. It also should win the respecting of a place and depend on the local forceful support to establish the Interactive University with the place.

The Interactive University is a new idea university by some government established to meet challenge of the 21 centuries. George Mason, the president of Virginia university, has used the two species significance of the name Interactive University. 
Firstly, he adopts this name to come to differentiate George Mason university to some other state priority "tradition university". "Johnson emphasizes that his university is really not to need to compete with University of Virginia, both of which is very important to American's future, because they are two completely unlike type of university; Secondary, he adopts this name to come to set forth development strategy university's led by him. He thinks the Interactive University's 'other places centre theory' is one important central idea of development strategy of George Mason university. His university is to be an important university of the Virginia, which need mutually the university to work together with the prompt development north part of Virginia State." (5)

The USA scholar thinks the definition of the Interactive University is that: "The fundamental development strategy of the Interactive University that the university should cooperate with its location community business circles, the public and the political circles leader to build up one kind of active, two-way effect buddy relation, and exert to achieve the community economic prosperity and public common goal of society. The dominant guiding principle of the Interactive University is to take 'other places as centre'. Therefore, school be ready not only and be able to admit the community citizen becoming the benefit that school develops relevance person or 'common property right person'. This new guiding principle for running a school are quite different from the tradition. Some important characteristic of tradition university is that school break away from society, acts as a role for a criticism person staying in so- ciety besides, is not to act a role as a society's active participator".

The enlightenment of the development of the Interactive University of USA to our new-built Area universities include the following two points: One is that the new-built area universities does not copy tradition key college's example blindly, the successful key of the higher university of the 21 centuries is to provide the characteristic social service to the part of the specially appointed society. Two is that the new-built universities ought to break some higher education's routine, to break through the function and the type restricting of the teaching type university, and to concentrate efforts on late-model universities construction to answer the new era change.

From the angle of the new-built colleges and universities development strategy we suggest the teaching serves type university and attempts to find one new kind of the new-built universities.

\section{References}

[1]http://classifications.carnegiefoundation.or $\mathrm{g} /$ methodology/community_engagement.p $\mathrm{hp}$.

[2] Shujie Wang, "The idea and practice of service type university abroad," Foreign education studies, 2008, (11)

[3] Luke - Richard, Peiwen Yu translation, "The company of the higher educationRise abruptly of making profit university," Peking University Press, PP.9-19, 2006.

[4] Chenhai Yu, Jinkuan Cheng, "The development pattern and outlook of the west service type university," Jiangsu Higher Education, 2009, (6)

[5][6] Ge Shouqin, Zhou Zhongshi, "USA state university and the local economic growth", Press of Northwest University, pp.200-204, 1983. 